\title{
Comparison of Parameters Affecting Flower Color in Gerbera hybrida: A Phytochemical Study on New Varieties
}

\author{
Abdollah Hatamzadeh ${ }^{1}$, Razieh Akbari ${ }^{1}$, Reyhaneh Sariri ${ }^{2}$ \& Davoud Bakhshi ${ }^{1}$ \\ ${ }^{1}$ Department of Ornamental Horticulture, Faculty of agriculture, University of Guilan, Iran \\ ${ }^{2}$ Department of Biochemistry, Faculty of Biology, University of Guilan, Iran \\ Correspondence: Razieh Akbari, Department of Ornamental Horticulture, University of Guilan, Rasht, Iran, Tel: \\ 98-131-669-0282. Email: R.Akbarii@ymail.com
}

Received: July 23, 2012 Accepted: August 6, 2012 Online Published: October 12, 2012

doi:10.5539/jas.v4n11p186 URL: http://dx.doi.org/10.5539/jas.v4n11p186

\begin{abstract}
Anatomical and biochemical studies of pigments in different varieties of Gerbera hybrida revealed the correlation of effective parameters on flower colors. Results showed that interactions of the parameters affecting color are different in various varieties, So that effect of co-pigmentation index occurred only in "Bastion" or interaction of biochemical and anatomical factors in "Rosalin" had presented a mat color in comparison to "Carmen" or "Purple Prince" with a velvety texture. Microscopic studies of epidermal cells confirmed presence of globular bodies in petal cell vacuoles of "Carmen", "Cacharell" and "Rosalin", while in "Purple Prince" revealed as masses or unformed packages. Also in Scanning Electronic Microscopic studies, epidermal cell shapes revealed as elongated cells with multiple papillae in all varieties, although their arrangement on epidermal cell surfaces varied in different varieties. The results of this study showed the role of relationships of anatomical and biochemical factors on gerbera flower colors in different varieties.
\end{abstract}

Keywords: cyanidin, pelargonidin, cell shape, pigment position, Gerbera hybrida

\section{Introduction}

Flower color is one of the most attractive characteristics of ornamental plants and contributes a dramatic part to their market value. Production of novel colors and color patterns in ornamentals is one of the attractive subjects of current plant biotechnology (Teeri \& Elomaa, 2003; Tanaka et al., 2005). In Gerbera, similar to many valuable flowers of composite family that do not produce blue colors, production of delphinidin-based anthocyanins is the dream and goal of many breeders. Moreover, color is an important factor for pollinators" attraction that can lead to enrichment of biological diversity (Noda et al., 1994).

Flower color is mainly based on the presence of two major groups of pigments: carotenoids and flavonoids. Red, blue and lilac flower colors are mainly provided by anthocyanins, an important flavonoid class, whereas yellow flower coloration is in most cases formed by carotenoids. However, in some plant species, yellow flower color is based on the presence of yellow flavonoids and the biosynthetically related anthochlor pigments (Karin et al., 2007). In general, flower coloration in the range of orange-red to red is determined by a combination of anthocyanins and/or carotenoids, as in the genera Chrysanthemum (Kishimoto et al., 2007) and Rosa (Yokoi \& Saito, 1973). The same tendency with respect to flower color and pigmentation has also been reported in orchidaceous plants (Tatsuzawa et al., 2005). Flowers acquire their characteristic due to these pigments in combination with other chemical and physical localization of pigments and the optical properties of petal epidermal cells (Kay et al., 1981; Mol et al., 1998).

Petal epidermal cell shape has been described for angiosperms (Christensen \& Hansen, 1998), Compositae (Baagoe, 1977), Primulaceae (Rosvik, 1969), Antirrhinum majus (Glover \& Martin, 1998) and Anagallis monelli L. (Quintana et al., 2007).

One of the other affecting factors on flower color is pigments situation in cells and presence of anthocyanic resources in vacuoles that considerably affect color intensity of many plant species. In most plants, these pigments are normally present dissolved uniformly in the vacuolar solution of epidermal cells. However, in certain species, the anthocyanins are localized in discrete regions of the cell vacuole. Such pigmented bodies have been described as "blue spherules" in epidermal rose petal cells (Yasuda, 1974), "intravacuolar spherical 
bodies" in Polygonum cuspidatum seedlings (Kubo et al., 1995), "ball-like structures" and "crystals" in stock, Matthiola incana, petals (Hemleben, 1981). These spherical bodies have been referred as "anthocyanoplasts" membrane-bound organelles providing intense coloration in the vacuoles of mature plant cells (Pecket \& Small, 1980). More recent reports have indicated that these globular inclusions possess neither a membrane boundary nor an internal structure (Nozzolillo, 1994; Cormier, 1997; Nozue et al., 1997). In the present study, we investigated the relationships of some important anatomical and biochemical factors such as major pigments of cyanidin and pelargonidin in this ornamental plant, as well as effect of anatomical parameters affecting of perception of flower final color, and compared them in six varieties of Gerbera with different colors. An understanding of such interactions and comparisons especially in different varieties is very valuable to flower color breeding programs.

\section{Materials and Methods}

\subsection{Plant Material}

Petals of six Gerbera varieties in different colors including; "Balance" (White), "Bastion" (Orange), "Carmen" (Red), "Rosalin" (Pink), "Purple Prince" (Purple) and "Cacharell" (Purplish pink) that were grown in a greenhouse under standard and identical condition (lat. $50^{\circ} 41^{\prime} \mathrm{N}$, long. $28^{\circ} 35^{\prime} \mathrm{E}$ ), collected the time of full bloom. The collected samples were kept in liquid $\mathrm{N}$ until used time. It should be mentioned that only ray florets studied in this study.

\subsection{Analysis of Flower Color}

Flower colors of the fresh outer ray florets from three flowers of each variety were evaluated by comparison with an RHS Color Chart (RHSCC; The Royal Horticultural Society, UK). A colorimetric instrument (CM-2002 Minolta Japan) was also used to measure the colors of fresh petals from three flowers of each variety, immediately after collection. Colors were expressed according to the Commission International de l' Eclairage (CIE) $L^{*} a^{*} b^{*}$ color-space coordinates.

\subsection{Determination of the Total "Flavones and Flavonols" Content}

Total "flavones and flavonols" content were determined using the spectrophotmetric method based on formation of complex with aluminium (Ordon et al., 2006). A volume of $0.5 \mathrm{ml}$ of $2 \% \mathrm{AlCl}_{3}$ methanol solution was added to $0.5 \mathrm{ml}$ of sample solution. After one hour at room temperature, the absorbance was measured by a PG Instrumen+T80 spectrophotometer. Total "flavones and flavonols" content was calculated using the equation based on the calibration curve.

\subsection{Analysis of Total Anthocyanins Content}

Plant material was ground in liquid nitrogen and freeze-dried for 2 day. $10 \mathrm{mg}$ of the powder was extracted with $1 \mathrm{ml}$ of extraction solvent $(70 \mathrm{ml}$ methanol $+20 \mathrm{ml}$ water $+10 \mathrm{ml} 1 \mathrm{M} \mathrm{HCl})$ at $4^{\circ} \mathrm{C}$ for $20 \mathrm{~h}$, and centrifuged $\left(7826 \times \mathrm{g}\right.$ for $20 \mathrm{~min}$ at $4^{\circ} \mathrm{C}$ ). There were three replicates for each sample. The absorbance of the supernatants was measured at $530 \mathrm{~nm}$. The anthocyanin content was calculated based on cyanidin chloride (Sigma) as a standard (Laitinen et al., 2008).

\subsection{Analysis of Total Carotenoids Content}

Carotenoids were extracted from petals $(1 \mathrm{mg})$ of each variety by soaking in $\mathrm{MeOH}$ : Acetone $(1: 1, \mathrm{v} / \mathrm{v} ; 1 \mathrm{ml})$ for $2 \mathrm{~h}$ at room temperature and the absorbance at $\lambda \max$ was used for quantitative analysis of carotenoids (Tatsuzawa et al., 2010).

\subsection{Analyses of Anthocyanidins}

Pigments were extracted from petals ( $1 \mathrm{~g}$ from each variety) by soaking in $20 \mathrm{ml}$ of $2 \mathrm{M} \mathrm{HCl}$ for $2 \mathrm{~h}$ at room temperature. The filtrated samples were hydrolyzed in a boiling water bath for $2 \mathrm{~h}$. After cooling, the reaction products were analyzed by analytical High Performance Liquid Chromatography (HPLC), using authentic anthocyanidins as standards. Analytical HPLC was performed on a Agilent 1100 system, using a reverse phase $\mathrm{C}_{18}(4.6 \times 250 \mathrm{~mm})$ column (Zorbax Eclipse), at $40^{\circ} \mathrm{C}$ with a flow rate of $1 \mathrm{ml} / \mathrm{min}$ monitoring at $530 \mathrm{~nm}$. The solvent was applied as a linear gradient system for 40 min from 20 to $85 \%$ solvent $\mathrm{B}$ ( $25 \% \mathrm{MeCN}, 20 \% \mathrm{HOAc}$, $1.5 \% \mathrm{H}_{3} \mathrm{PO}_{4}$ in $\left.\mathrm{H}_{2} \mathrm{O}\right)$ in solvent $\mathrm{A}\left(1.5 \% \mathrm{H}_{3} \mathrm{PO}_{4}\right.$ in $\left.\mathrm{H}_{2} \mathrm{O}\right)$ (Tatsuzawa et al., 2010).

\subsection{Analysis of $\beta$-caroten}

An acetone extract of fresh petals $(0.5 \mathrm{~g})$ was partitioned between diethyl ether and aqueous $\mathrm{NaCl}$. The organic layer was washed with water, and the residue was saponified with equivalent $5 \% \mathrm{KOH}-\mathrm{MeOH}$ for $1 \mathrm{~h}$ at room temperature. The saponified matter was then extracted with diethyl ether and washed with water. The organic 
layer was dried and dissolved in $1 \mathrm{ml} \mathrm{MeOH}$ and used in quantitative and HPLC analyses. Each extract was analyzed by HPLC, on a Young Lin Acme 9000 system, using a reverse phase $C_{18}(4.6 \times 250 \mathrm{~mm})$ column (Lichrosphere $\mathrm{Rp} \mathrm{100)}$ under the following conditions: solvent $\mathrm{A}$, methanol $(\mathrm{MeOH}) /$ methyl tert-butyl ether $(\mathrm{MTBE}) / \mathrm{H}_{2} \mathrm{O}=90: 6: 4(\mathrm{v} / \mathrm{v} / \mathrm{v}) ;$ solvent $\mathrm{B}, \mathrm{MeOH} / \mathrm{MTBE} / \mathrm{H}_{2} \mathrm{O}=25: 71: 4$; gradient, 0/100, 12/100, 96/0 $(\mathrm{min} / \% \mathrm{~A})$; flow rate, $1.0 \mathrm{~mL} \cdot \mathrm{min}^{-1}$; column temperature, $35^{\circ} \mathrm{C}$ (Kishimoto et al., 2007).

\subsection{Anatomical Analysis}

The Petal adaxial surfaces of fully open mature flowers were coated with $30 \mathrm{~A}^{\circ}$ gold in a Polavon Sputter coater (3AL-TEC SCD 005) and were the subject of micro morphological studies using a PHILIPS XL 30 scanning electron microscope at an acceleration voltage of $15 \mathrm{KV}$. Presence and situation of vacuolar resources in different regions of fresh petal tissues were analyzed using a Nikon ALPHAPHOT/YS light microscope without no preprocessing or staining during sample preparation. For each variety, 12-36 samples were studied.

\subsection{Statistical Analysis}

For statistical analysis of data, a completely randomized design with three replications was used. Significant differences were found at $\mathrm{P}<0.05$ using Duncan's Multiple Range Test. Also analysis of variance of data and correlations between petal color parameters and other factors were made using SPSS (13.0 for Windows; SPSS Inc., Chicago, IL).

\section{Results and Discussion}

Flower color was distributed on CIELAB color coordinate was follow; the highest values of $L^{*}, a^{*}, b^{*}, C^{*}$ and $h$ in "Balance", "Purple Prince", "Bastion", "Bastion" and "Balance" and the lowest of them found in "Carmen", "Balance", "Cacharell", "Balance" and "Cacharell", respectively. The visual characteristics of color, including color name and code, also CIELAB color parameters have presented according to RHSCC and CIELAB system in Table 1.

Table 1. Petal color parameters of six Gerbera varieties

\begin{tabular}{ccccccccc}
\hline & & \multicolumn{3}{c}{ RHSCC $^{\mathrm{a}}$} & \multicolumn{3}{c}{ coordinate $^{\mathrm{b}}$ CIELAB } \\
\cline { 3 - 9 } No. & Variety & Code & Name & $L^{*}$ & $a^{*}$ & $b^{*}$ & $C^{*}$ & $h^{\mathrm{c}}$ \\
\hline 1 & Balance & - & White & 86.30 & -3.62 & 18.95 & 19.29 & 100.81 \\
2 & Bastion & $31 \mathrm{~B}$ & Strong reddish orange & 42.91 & 48.62 & 66.80 & 82.63 & 53.95 \\
3 & Carmen & 44C & Vivid reddish orange & 32.27 & 56.40 & 51.67 & 76.49 & 42.49 \\
4 & Rosalin & 36C & Light yellowish pink & 73.10 & 24.60 & 20.56 & 32.06 & 39.89 \\
5 & Purple Prince & 67B & Vivid purplish red & 34.36 & 61.08 & 28.78 & 67.56 & 25.30 \\
6 & Cacharelle & 68B & Strong purplish pink & 49.77 & 53.39 & 21.16 & 53.40 & 1.25 \\
\hline
\end{tabular}

${ }^{a}$ RHSCC (The Royal Horticultural Society Color Chart);

${ }^{\mathrm{b}} L^{*}$ : lightness; $a^{*}, b^{*}$ : chromatic components; $C^{*}$ : Chroma;

${ }^{\mathrm{c}}$ Hue angle $(h)=\arctan \left(b^{*} / a^{*}\right)\left({ }^{\circ}\right)$.

Based on CIELAB coordinates, the attributes of the visually colors of Cacharell and Bastion petals showed medium lightness $\left(L^{*}=45-50\right)$, and a saturation level of higher than 50 . This can be characteristic of "Strong" colors (RHS codes: 68B and 31B). Also, Balance and Rosalin varieties, revealed the highest $L^{*}$ value and the lowest values of $a^{*}, b^{*}$ and $C^{*}$ that certainly is due to presence of the most total flavonol and flavones contents (Table 2).

Also, According to CIELAB parameters, Carmen and Purple Prince varieties, showed similar quantitative antocyanin contents (the most total anthocyanin contents), the highest values of $a^{*}$ as well as $C^{*}$ (higher than 65 value) and the lowest values of $L^{*}$ in comparison to other varieties. These varieties significantly were darker. This can be characteristic of "vivid" colors (RHS codes: 44C and 67B) in Gerbera flowers.

The highest $b^{*}$ and $C^{*}$ values revealed in Bastion (RHS code= 31B). A possible explanation may be that $b^{*}$ parameter describes the yellowness due to the presence of yellow pigments, which are generally products of the 
carotenoid synthesis such as $B$ carotene. As, Bastion contained the highest contents of total carotenoid, too. According to results (table 2), because of Carmen and Purple Prince varieties showed similar quantitative anthocyanin and flavonoide amounts in petals, it is confirmed that Presence of $\beta$ carotene and total carotenoids affecting final color of flowers. This implies that total carotenoids can be decrease or increase the color changes caused by total anthocyanins or by interactions between types of anthocyanins and carotenoids. Such relations only is observed in varieties of orange - red hued (RHS code: $44 \mathrm{C}, 31 \mathrm{~B}$ and $67 \mathrm{~B}$ ), so that with increasing $b^{*} / a^{*}$, petal colors tend to orange colors similar to Bastion $\left(a^{*}\right.$ value $=48.62, b^{*}$ value $\left.=66.80\right)$. In addition, a combination of cyanidin-based anthocyanins and carotenoids resulted in more redness, as the precence of pelargonidin decreased $b^{*}$ value and increased $a^{*}$ value in Purple Prince in comparison to Carmen.

So, the ratio of the amounts of total anthocyanin and total carotenoid seem to be important factors to describe flower colors in such cases, and by changing the ratio, various degrees of orange colors can be obtained.

Table 2. Pigment contents in Gerbera varieties

\begin{tabular}{|c|c|c|c|c|c|c|c|c|}
\hline No. & Variety & $\begin{array}{l}\text { Cyanidin } \\
\text { (\% of total } \\
\text { anthocyanin) }\end{array}$ & $\begin{array}{c}\text { Pelargonidin } \\
\text { (\% of total } \\
\text { anthocyanin) }\end{array}$ & $\begin{array}{l}\text { B-caroten } \\
\text { (\% of total } \\
\text { carotenoid) }\end{array}$ & $\begin{array}{c}\text { Total } \\
\text { anthocyanin } \\
(\mathrm{mg} / 100 \mathrm{~g} \mathrm{FW})\end{array}$ & $\begin{array}{l}\text { Total flavones } \\
\text { and flavonols } \\
(\mathrm{mg} / 100 \mathrm{~g} \mathrm{FW})\end{array}$ & $\begin{array}{c}\text { Total } \\
\text { carotenoid } \\
(\mathrm{mg} / 100 \mathrm{~g} \mathrm{FW})\end{array}$ & $(\mathrm{CI})^{*}$ \\
\hline 1 & Balance & $\mathrm{nd}^{* *}$ & nd & nd & - & $17.21 \mathrm{a}$ & - & - \\
\hline 2 & Bastion & 100 & nd & 2.1 & $1.01 \mathrm{~d}$ & $5.57 \mathrm{c}$ & $3.99 \mathrm{a}$ & $5.50 \mathrm{a}$ \\
\hline 3 & Carmen & 100 & nd & 1.3 & $21.94 \mathrm{a}$ & $2.12 \mathrm{~d}$ & $3.85 \mathrm{~b}$ & $0.09 \mathrm{c}$ \\
\hline 4 & Rosalin & 97.6 & 2.4 & nd & $10.14 \mathrm{c}$ & $15.17 \mathrm{~b}$ & - & $1.50 \mathrm{~b}$ \\
\hline 5 & Purple Prince & 86.9 & 3.1 & 0.3 & $21.94 \mathrm{a}$ & $2.14 \mathrm{~d}$ & $0.55 \mathrm{c}$ & $0.10 \mathrm{~d}$ \\
\hline 6 & Cacharelle & 99.8 & 1.2 & nd & $16.13 \mathrm{~b}$ & $2.15 \mathrm{~d}$ & - & $0.13 \mathrm{c}$ \\
\hline
\end{tabular}

${ }^{*} \mathrm{CI}$ : Co-pigmentation Index, $\mathrm{CI}=\mathrm{TF} / \mathrm{TA}$;

** nd: no detected*.

In this study, $L^{*}$ value showed a significant and negative correlation with $a^{*}, b^{*}$ and $C^{*}$ parameters, but a significant and positive correlation found between $a^{*}$ and $C^{*}$ values too. In study of relationship of total anthocyanin content and $L^{*}$ parameter revealed a significant and negative correlation, this means that the darker petals, had the more TA amounts and the less lightness. Such results were reported in experiments of Jia et al., (2008) in purple- and pink- colored flowers too. The most of total anthocyanin amounts found in "Cacharell" and "Carmen" (29.4 mg/g FW) and the lowest amount of it found in "Bastion", orange colored, (1.01 mg/g FW) (Table 2). Also the most of total "flavones and flavonols" amounts related to "Balance", white colored; this indicates that "Balance" lacked a pure white color, as it lacked carotenoids and anthocyanins, too.

Flavonols are usually colourless or pale yellow, and are derived from dihydroflavonols through enzymatic conversion by flavonol synthase and may affect final flower color by being yellow, and mixing with reddish anthocyanins to give a final orange color; by absorbing UV and thus changing final flower color; by competing with the anthocyanin synthetic pathway for dihydroflavonol and thus reducing the final concentration of anthocyanin produced (Holton et al., 1993).

Since the ratio of total flavonols and flavones to total anthocyanins in Bastion was relatively high; probability of complex formation between these molecules and enhance anthocyanin color is high in this variety. It has confirmed that flavonols and flavones act as co-pigments, and are thought to form stacked complexes with anthocyanin, causing a shift in the absorption spectrum of the anthocyanin molecule and thus considerably affect on final colors of flowers (Mol et al., 1998). So, co-pigmentation effect which was expected to occur when the TF/TA ratio exceeded 5 (Asen, et al., 1971), was revealed in "Bastion"; orange variety (CI=5.50).

In study of anthocyanidin and $B$-carotene amounts, results showed that pink group varieties; "Cacharell" and "Rosalin", nearly lacked B-carotene, moreover, petals color in orange, red and purple varieties; "Bastion", "Carmen" and "Purple Prince", confirmed that is due to interaction of carotenoids and anthocyanins (Table 2). Also, in "Carmen" and "Bastion", only cyanidin contributed with carotenoids in petals coloration. "Balance" 
lacked cyanidin, Pelargonidin and ß-caroten pigments. Also, pelargonidin not observed in "Bastion" and "Carmen" at all. So, Results show that relationships of flower color parameters and anthocyanins of cyanidin and pelargonidin (in "Cacharell" and "Purple Prince" and "Rosalin" varieties) and carotenoids (except of "Balance" that lacked any pigments) are similar to flowers of Chrysanthemum morifolum and Rosa spp. (Kishimoto et al., 2007; Yokoi \& Saito, 1973), and Disa (Tatsuzawa et al., 2010). Kishimoto et al. (2007) have provided a good example of how pigment compositions affect flower color. They looked at the pigment composition of nine species of plants in the same family - Compositae (Asteraceae). Varieties were analyzed for carotenoid and anthocyanin composition. Orange and yellow flowers were seen to contain yellowish carotenoids, but there were seen to be three possibilities, which allow flowers to be more clearly orange. These included anthocyanins at higher levels than in the yellow flowers (in Chrysanthemum morifolium Ramat., Gerbera jamesonii Bolus, and Zinnia elegans Jacq.) or carotenoids at higher levels than in the yellow flowers (in Helianthus annuus L., Tagetes erecta L. and Tagetes patula L.) or have more of the reddish carotenoids than in the yellow flowers (in Calendula officinalis L., Gazania spp and Osteospermum ecklonis). The first object that shows participation of anthocyanins and carotenoids in flowers coloration is confirmed in our studies in "Bastion" because of presence of the highest of $\beta$-carotene content and cyanidin contents, also in this study, results showed that although in "Bastion", total carotenoid amounts nearly is four fold of total anthocyanin amounts , but the presence of specific types of anthocyanins such as cyanidins that produce a more density of colors in flowers, accompanied by reddish carotenoids, can be resulted to more orange coloration in flowers. In Cattleya, the flower colors in the yellow to orange range are determined by carotenoids, in the orange to red range by combination of anthocyanins and carotenoids, and in the red to purple range by anthocyanins (Tatsuzawa et al., 1998). So, it confirmed that interactions of anthocyanins and carotenoids resulted colors of orange-red and red in Gerbera, too.

Table 3. Correlation coefficients of effective parameters on flower color in Gerbera varieties

\begin{tabular}{ccccccccc}
\hline & TA & TF & TC & CI & $\mathrm{L}^{*}$ & $\mathrm{a}^{*}$ & $\mathrm{~b}^{*}$ & $\mathrm{C}^{*}$ \\
\hline $\mathrm{TA}$ & 1 & $-0.70^{* *}$ & 0.26 & $-0.57^{*}$ & $-0.68^{* *}$ & $0.72^{* *}$ & -0.14 & $0.96^{* *}$ \\
$\mathrm{TF}$ & 1 & $-0.64^{* *}$ & 0.005 & $0.95^{* *}$ & $-0.97^{* *}$ & -0.25 & $-0.80^{* *}$ \\
$\mathrm{TC}$ & & & 1 & $0.55^{*}$ & $-0.80^{* *}$ & $0.70^{* *}$ & $0.84^{* *}$ & 0.40 \\
$\mathrm{CI}$ & & & 1 & -0.12 & 0.08 & $0.70^{* *}$ & $-0.47^{*}$ \\
$\mathrm{~L}$ & & & & 1 & $-0.97^{* *}$ & $-0.48^{*}$ & $-0.80^{* *}$ \\
$\mathrm{a}^{*}$ & & & & & 1 & 0.30 & $0.80^{* *}$ \\
$\mathrm{~b}^{*}$ & & & & & & 1 & 0.05 \\
$\mathrm{C} *$ & & & & & & & & 1 \\
\hline
\end{tabular}

* Correlation is significant at the 0.05 level; ** Correlation is significant at the 0.01 level.

In analysis of interaction of CIELAB parameters with amounts of pigments, a negative correlation observed between total anthocyanin and parameters of $L^{*}$ and $b^{*}$, furthermore a significant and positive correlation found between total antocyanins, and $a^{*}$ and $b^{*}$ parameters (Table 3 ). This indicates that intensity of flower color increase according to increase in anthocyanin. This condition in "flavones and flavonols" is completely converse. According to obtained results, a significant and negative correlation found among total "flavones and flavonols" amounts, and $a^{*}$ and $C^{*}$ parameters, and a positive correlation with $L^{*}$ value too, the higher "flavones and flavonols" amounts, the lower $C^{*}$ and higher lightness flowers had, as a negative correlation observed between anthocyanins and "flavones and flavonols" $\left(\mathrm{R}^{2}=-0.70\right)$ too. Also CI indicated a negative correlation with anthocyanin contents. The lower anthocyanin contents, the more interference of other "flavones and flavonols" there was. Also a negative correlation observed between carotenoid amounts and $L^{*}$ value. This indicates that lightness of color in petals contained carotenoid isn't due to presence of yellow pigments. 

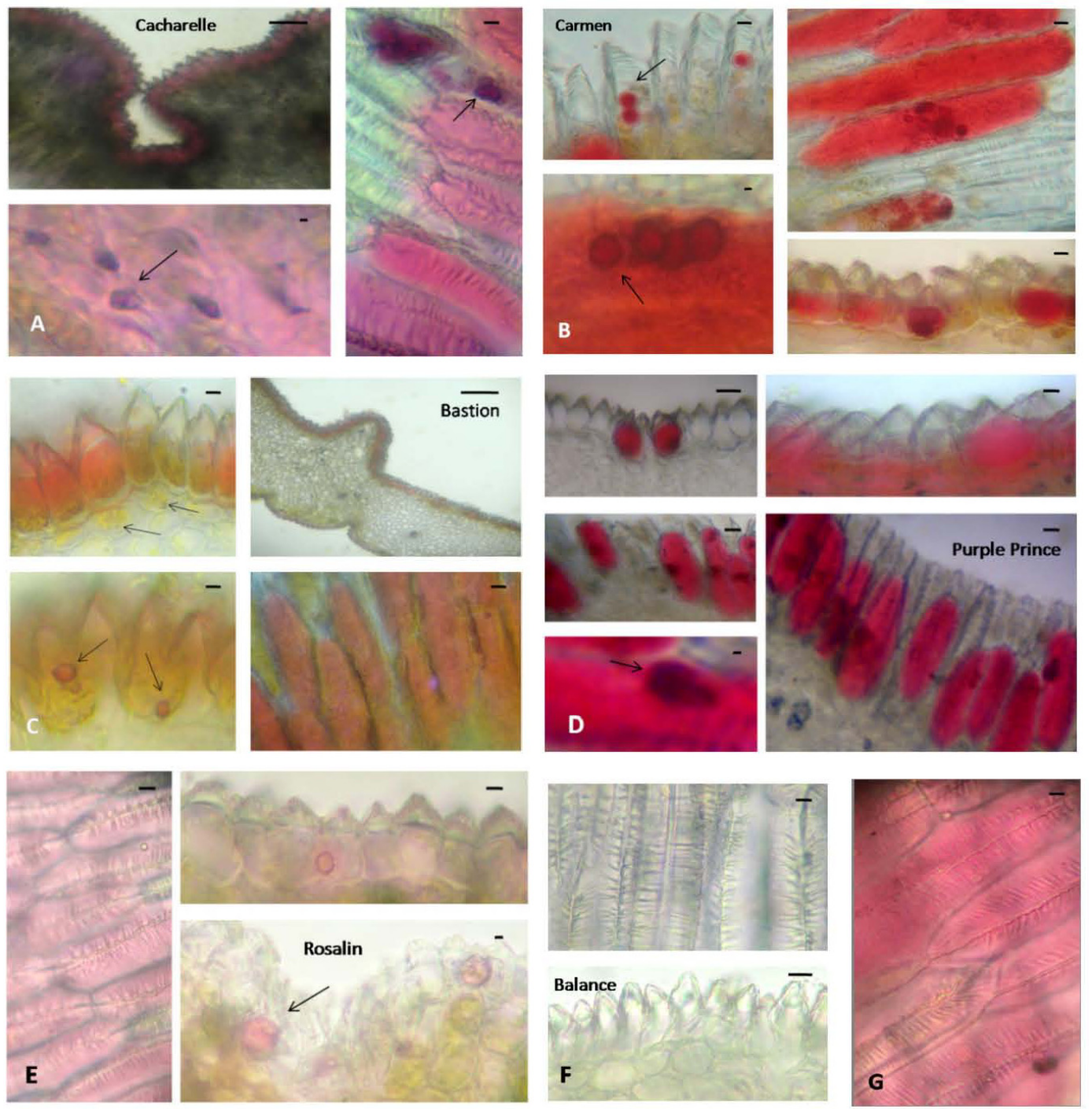

Figure 1. Anthocyanic vacuolar inclusions (AVI) and pigments position in epidermal cells

A. present Presence of anthocyanins into epidermal tissues of Cacharell petal, arrows shows AVI as different shapes of regular and irregular into papillae and epidermal cells;

B. compactness and situation of cyanic pigments is clear into epidermal cells. of Carmen petals, AVI into papillae observed as spherical organelles with border membranes;

C. present position of pigments in Bastion petals. Yellow pigments have located into mesophyll cells. In this variety interaction of between beta-carotene, cyanidin and flavonoids present orange color of petals. Presence of red deposits (AVI) inside a yellow background is visible;

D. showing accumulation of anthocyanins into papillae of Purple Prince petals that was the higher than the other cyanic variety. Anthocyanic masses present without no surrounding membranes and no regular shapes;

E. presents situation of pigments in epidermal cells of Rosalin petals. The arrow showing a spherical body into papillae in diameter of 12 microns;

F. showing epidermal cells in "Balance" - white colored- without no pigments (longitudinal and cross sections of petal in above and below, respectively) and G. showing elongated cells with multiple papillae in upper petal surfaces by light microscopic analysis, typically. The bars from small to large are 4, 10, 40 and $100 \mu \mathrm{m}$, respectively. 


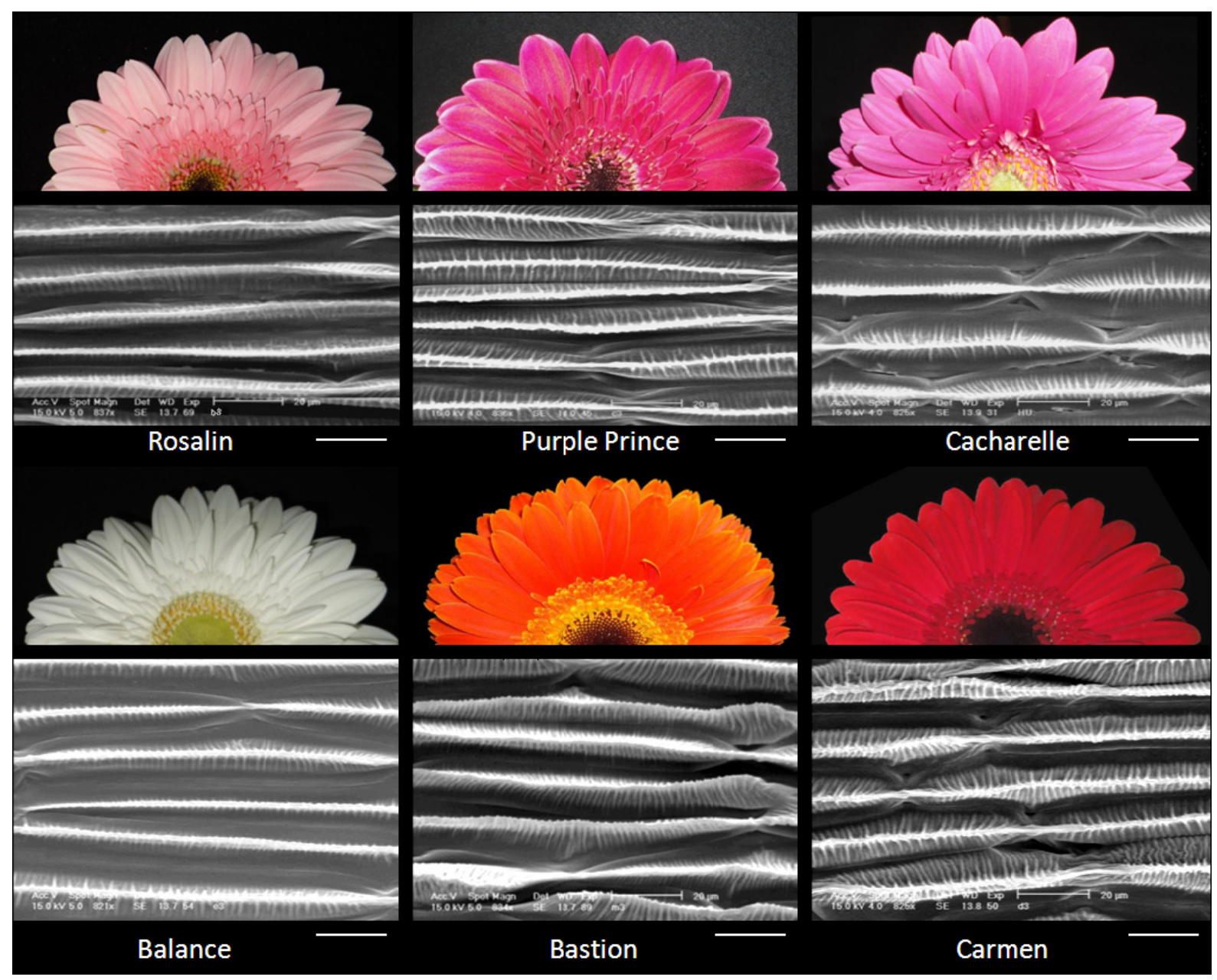

Figure 2. SEM picture of the upper epidermal surface showing petals central part with multiple papillae on elongated epidermal cells

Bars are $20 \mu \mathrm{m}$.

Microscopic studies showed that anthocyanins accumulate in vacuole of epidermal cells, mostly into papillae (Figure 1 A-E); and carotenoids in mesophyll cells of petals (Figure 1 C). As, Vogelpoel (1995) described that anthocyanins in Disa occur in the epidermal cells of the perianth and carotenoid are found in the mesophyll cells.

The varieties containing high anthocyanin contents, such as "Carmen" and "Purple Prince", enriched from anthocyanic resources into vacuoles (Figure 1. A, B \& D). Anthocyanic bodies in all cyanic varieties of Gerbera, observed as different shapes, so that in "Carmen" presented as globular bodies with a membrane boundary similar to AVI in spider flower (Cleom hassleriana) that was studied by Nozzolillo et al. (2010) with this difference that in Cleom globular bodies found inside mesophyll cells. In "Purple Prince", anthocyanins only observed as much density masses that had no spherical or other regular shapes (Figure 1 D). Such situation was similar to AVI in Eustoma grandiflorum that studied by Markham et al. (2000), so that electron microscopy studies on lisianthus epidermal tissue failed to detect a membrane boundary in AVI bodied. In carnation, membranesless proteinaceous matrixes referred to "trap" anthocyanins (Grotewold, 2006). In petal cells of "Balance", as microscopical results showed, no coloration observed (Figure $1 \mathrm{~F}$ ).

In SEM studies, cell shapes in longitudinal section observed as elongated cells, relatively wide and angular in end (Figure $1 \mathrm{G}$ ). Papillae observed as different arrangements on surfaces of upper epidermal cells in various varieties. Papillae were compacted densely in varieties that had more color intensity and vice versa; there was lower compactness in white and pink varieties (Figure $2 \& 3$ ). These differences indicate that cell shapes with incident light proportion alternation can be affect on flower color; moreover, this reveal genotype differences and 
its effect on flower color in various varieties. As, Noda et al. (1994) reported that Conical cells in comparison to flat cells increase the proportion of incident light that enters epidermal cells, enhancing light absorption by the pigments and thus the intensity of color.

Also, our results confirm that flower color is correlated with the visible anthocyanin content or epidermal cells color (Figure 1). Figure 2 presents cell shapes, arrangements, and compactness of papillae on epidermal cells in various varieties.

\section{Conclusion}

According to results, interactions of different parameters affecting color have a determinant role in perception of petals final color in Gerbera. In different varieties, some of parameters had a more apparent role, such as interference of anthocyanins and carotenoids in final color of flowers in "Bastion". "Balance", white colored, lacked any colored pigments. In pink to purple-red varieties, presence of anthocyanins was more apparent and in such cyanic varieties, interaction of various anthocyanins plays a more effective role on final color of petals. Also, anatomical studies determined that varieties with more anthocyanin contents in vacuoles, such as "Carmen" and "Purple Prince", due to presence of more compactness and more irregular papillae have a more velvety texture than other varieties. In cyanic varieties, except of "Purple Prince" that AVI only observed as masses or unshaped packages, in others observed as different shapes including globular bodies in vacuole. This indicates that in various varieties, different types of anthocyanic accumulations in vacuole can occurred. Also, our results showed relationship of anatomical and biochemical characteristics affecting flower colors in Gerbera varieties.

\section{Acknowledgments}

The financial support by University of Guilan is highly appreciated.

\section{References}

Asen, S., Stewart, R. N., \& Norris, K. H. (1971). Co-pigmentation effect of quercetin glycosides on absorption characteristics of cyanidin glycosides and color of Red Wing azalea. Phytochemistry, 10, 171-175. http://dx.doi.org/10.1016/S0031-9422(00)90266-8

Baagoe, J. (1977). Microcharacters in the ligules of the compositae. The Biology and Chemistry of the Compositae. New York: Academic Press.

Christensen, K. I., \& Hansen, H. V. (1998). SEM-studies of epidermal patterns of petals in the angiosperms. Opera Botanica, 135, 5-86. http://dx.doi.org/CAT11062898

Cormier, F. (1997). Food colourants from plant cell cultures. New York: Plenum Press.

Glover, B. J., \& Martin, C. (1998). The role of petal cell shape and pigmentation in pollination success in Antirrhinum majus. Heredity, 80, 778-784. http://dx.doi.org/10.1046/j.1365-2540.1998.00345.x

Grotewold, E. (2006). The genetics and biochemistry of floral pigments. Annuals Review of Plant Biology, 57, 761-780. http://dx.doi.org/10.1146/annurev.arplant.57.032905.105248

Hemleben, V. (1981). Anthocyanin carrying structures in specific genotypes of Matthiola incana R. Br. Journal of Zeitschrift fur. Naturforschung, 36c, 925-927.

Holton, T. A., Brugliera, F., \& Tanaka. Y. (1993). Cloning and expression of flavonol synthase from Petunia hybrida. Plant Journal, 4, 1003-1010. http://dx.doi.org/10.1046/j.1365-313X.1993.04061003.x

Jia, N., Shu, Q., Wang, L., Du, H., Xu, Y., \& Liu, Z. (2008). Analysis of petal anthocyanins to investigate coloration mechanism in herbaceous peony cultivars. Scientia Horticulturae, 117, 167-173. http://dx.doi.org/10.1016/j.scienta.2008.03.016

Karin Schlangen, K., Halbwirth, H., Topuz, F., Miosic, S., Seitz, C., \& Stich, K. (2007). Breeding for yellow flower color. Journal of. Biotechnology, 131s, S32-S35.

Kay, Q. O. N., Daoud, H. S., \& Stirton, C. H., (1981). Pigment distribution, light reflection and cell structure in $\begin{array}{lllll}\text { petals. Botanical Journal of Linnean Society, } & 83, & \text { 57-84. }\end{array}$ http://dx.doi.org/10.1111/j.1095-8339.1981.tb00129.x

Kishimoto, S., Sumimoto, K., Yagi, M., Nakayama, M., \& Ohmiya, A. (2007). Three routes to Orange petal colour via carotenoid components in 9 Compositae species. Journal of the Japanese Society for Horticultural Science, 76, 250-257. http://dx.doi.org/10.2503/jjshs.76.250

Kubo, H., Nozue, M., Kawasaki, K., \& Yasuda, H. (1995). Intravacuolar spherical bodies in Polygonum cuspidatum. Plant Cell Physiology, 36, 1453-1458. 
Laitinen, A. E, R., Ainasoja, M., K., Broholm, S., H., Teeri, T., \& Elomaa, P. (2008). Identification of target genes for a MYB-type anthocyanin regulator in Gerbera hybrida. Journal of Experimental Botany, 13, 3691-3703. http://dx.doi.org/10.1093/jxb/ern216

Markham, K. R, Gould, K. S., Winefield, C. S., Mitchell, K. A., Bloor, S., \& Boase, M. R. (2000). Anthocyanic vacuolar inclusions-their nature and significance in flower coloration. Phytochemistry, 55, 327-336. http://dx.doi.org/10.1016/S0031-9422(00)00246-6

Mol, J., Grotewold, E., \& Koes, R. (1998). How genes paint flowers and seeds. Trends in Plant Science, 3, 212-217. http://dx.doi.org/10.1016/S1360-1385(98)01242-4

Noda, K. I., Glover, B. J., Linstead, P., \& Martin, C. (1994). Flower color intensity depends on specialized cell shape controlled by a Myb-related transcription factor. Nature, 369, 661-664. http://dx.doi.org/10.1038/369661a0

Nozzolillo, C., Amiguet, C., Bily, A. S., Harris, C., Saleem, A., Andersen, O. M., \& Jordheim, M. (2010). Novel aspects of the flowers and floral pigmentation of two Cleome species (Cleomaceae), C. hassleriana and $C$. serrulata. Biochemical Systematics and Ecology, 38, 361-369. http://dx.doi.org/10.1016/j.bse.2010.03.005

Nozzolillo, C. (1994). Anthocyanoplasts: organelles or inclusions? Polyphenols Actualites, 11, 16-18.

Nozue, M., Yamada, K., Nakamura, T., Kubo, H., Kondo, M., \& Nishimura, M. (1997). Expression of a vacuolar protein (VP24) in anthocyanin-producing cells of sweet potato in suspension culture. Plant Physiology, 115, 1065-1072. http://dx.doi.org/10.1104/pp.115.3.1065

Ordonez, A. A. L., Gomez, J. D., Attuone, M. A., \& Isla, M. I. (2006). Antioxidant activities of Sechium edule (Jacq.) Swart extracts. Food Chemistry, 97, 452-458. http://dx.doi.org/10.1016/j.foodchem.2005.05.024

Pecket, R. C., \& Small, C. J. (1980). Occurrence, location and development of anthocyanoplasts. Phytochemistry, 19, 2571-2576. http://dx.doi.org/10.1016/S0031-9422(00)83921-7

Quintana, A., Albrechtova, J., Griebach, R. J., \& Freyre, R. (2007). Anatomical and biochemical studies of anthocyanidins in flowers of Anagallis monelli L. hybrids. Scientia Horticulturae, 112, 413-421. http://dx.doi.org/10.1016/j.scienta.2007.01.024

Rosvik, A. (1969). Investigations on Petal Epidermis and Its Bearing on Taxonomy in Primulaceae. Bergen, Norwegian Universities Press.

Tanaka, Y., Katsumoto, Y., Brugliera, F., \& Mason, J. (2005). Genetic engineering in floriculture. Plant Cell, Tissue and Organ Culture, 80, 1-24. http://dx.doi.org/10.1007/s11240-004-0739-8

Tatsuzawa, F., Ichihara, K., Shinoda, K., \& Miyoshi, K. (2010). Flower colors and pigments in Disa hybrid (Orchidaceae). South African Journal of Botany, 76, 49-53. http://dx.doi.org/10.1016/j.sajb.2010.02.089

Tatsuzawa, F., Yukawa, T., Shinoda, K., \& Saito, N., (2005) Acylated anthocyanins in the flowers of genus Dendrobium section Phalaenanthe (Orchidaceae). Biochemical Systematics and Ecology, 33, 625-629. http://dx.doi.org/10.1016/j.bse.2004.11.007

Tatsuzawa, F., Saito, N., Yokoi, M., Shigihara, A., \& Honda, T. (1998). Acylated cyanidin glycosides in the $\begin{array}{llll}\text { orange-red flowers of Sophronitis coccinea. Phytochemistry, 49, } & \text { 869-874. }\end{array}$ http://dx.doi.org/10.1016/S0031-9422(98)00182-4

Teeri, T. H., \& Elomaa, P. (2003). Genetic modification, applications. Flower color. In: Thomas B, Murphy DJ, Murray BG (eds). Encyclopedia of applied biosciences. Academic Press.

Vogelpoel, L. (1995). Green, yellow, white and black colors in orchid flowers. Part 2-some observations on pigments of plastid origin - continued. South Africa Orchid Journal, 26, 87-90.

Yasuda, H. (1974). Studies on "bluing effect" in the petals of red rose II. Observation on the development of the tannin body in the upper epidermal cells of bluing petals. Cytologia, 39, 107-112.

Yokoi, M., \& Saito, N. (1973). Light absorption patterns of intact Rosa flowers in relation to the flower color. Phytochemistry, 12, 1783-1786. http://dx.doi.org/10.1016/0031-9422(73)80402-9 